Research highlights

- Fit-for-purpose soil leaching tests for stabilization of $\mathrm{Cr}(\mathrm{III})$ in soil by lignite addition.

- $90 \%$ and $60 \%$ of $\mathrm{Cr}(\mathrm{III})$ were immobilized in calcareous and acidic soil per se, respectively.

- Calcareous soil immobilizes $\mathrm{Cr}$ rendering it unavailable for stabilization by lignite.

- Lignite stabilizes $\mathrm{Cr}$, being mobilized in acidic soil.

- $\mathrm{Cr}(\mathrm{III})$ stabilization in acidic soil efficient by lignite of close particle size range. 


\section{Optimization of lignite particle size for stabilization of trivalent chromium}

\section{in soils}

Timothy Anemana ${ }^{1,2}$, Mihály Óvári ${ }^{3}$, Ágnes Szegedi ${ }^{4}$, Nikolett Uzinger ${ }^{5}$, Márk Rékási ${ }^{5}$, Enikő Tatár ${ }^{1,2}$, Jun Yao ${ }^{6}$, Christina Streli ${ }^{7}$, Gyula Záray ${ }^{1,2,3}$, Victor G. Mihucz ${ }^{1,2 *}$

${ }^{1}$ Laboratory for Environmental Chemistry and Bioanalytics, Institute of Chemistry, ELTE Eötvös Loránd University, H-1117 Budapest, Pázmány Péter stny. 1/A, Hungary

${ }^{2}$ Hungarian Satellite Centre to Trace Elements Institute for UNESCO, Institute of Chemistry, ELTE - Eötvös Loránd University, H-1117 Budapest, Pázmány Péter stny. 1/A, Hungary

${ }^{3}$ MTA Centre for Ecological Research, Danube Research Institute, H-1113 Budapest, Karolina út 29, Hungary

${ }^{4}$ Green Chemistry Research Group, Institute of Materials and Environmental Chemistry, MTA Research Centre for Natural Sciences, H-1117 Budapest, Magyar Tudósok körútja 2, Hungary

${ }^{5}$ MTA Centre for Agricultural Research, Institute for Soil Science and Agricultural Chemistry, H-1022 Budapest, Herman Ottó út 15, Hungary

${ }^{6}$ School of Water Resource and Environment Engineering, China University of Geosciences in Beijing, 29 Xueyuan Road, Haidian District, Beijing, 100083, China

${ }^{7}$ Atominstitut, Technische Universität Wien, A-1020 Vienna Stadionallee 2, Austria

* Corresponding author: Phone: +36-1-372-2607; Fax: +36-1-372-2608; E-mail: mihuczviktor@caesar.elte.hu 


\begin{abstract}
Stabilization capacity of $5 \%$ by weight lignite added in three particle size ranges $(<0.5 ; 0.5-$ 1.0 and $1.0-2.0 \mathrm{~mm})$ to acidic $(\mathrm{pH}=5.0)$ or calcareous $(\mathrm{pH}=7.7)$ sandy soil samples of $<2$ $\mathrm{mm}$ grain size artificially contaminated with $375 \mathrm{mg} / \mathrm{kg} \mathrm{Cr}$ (III) was assessed through fit-forpurpose leaching tests performed with $\mathrm{CH}_{3} \mathrm{COOH}, \mathrm{NH}_{2} \mathrm{OH} \cdot \mathrm{HCl}$ and EDTA. About $90 \%$ and $60 \%$ of $\mathrm{Cr}$ (III) was immobilized in calcareous and acidic soils per se, respectively. Although the point of zero charge measurements $\left(\mathrm{pH}_{\mathrm{pzC}} \approx 4.5\right)$ indicated that lignite could effectively bind positively charged $\mathrm{Cr}$ hydroxo complexes at the $\mathrm{pH}$ of the calcareous soil, application of lignite is unnecessary due to the low solubility of these species. Although the acidic soil mobilizes $\mathrm{Cr}$, addition of lignite has been proven to stabilize it. The phytoavailable $\mathrm{Cr}$ fraction in the soils per se was about $10-25 \%$. In spite of the mobilization of $\mathrm{Cr}$ by acidic soil, the phytoavailable $\mathrm{Cr}$ concentration decreased to about half when the lignite particle size was either $0.5-1.0$ or $1.0-2.0 \mathrm{~mm}$. Lignite was suitable for Cr stabilization in acidic soil in a close particle size range, ensuring the dispersibility needed to enhance efficient $\mathrm{Cr}$ transfer from the contaminated soil to the stabilizer.
\end{abstract}

Keywords: Brown coal; Community Bureau of Reference; Leaching; Phytoavailability; Soil contamination. 


\section{Introduction}

Chromium is a metal, of which toxicity depends on its oxidation state (Metze et al., 2003). Among the stable Cr species, the highly oxidized Cr(VI), classified as "Group A" human carcinogen by United States Environmental Protection Agency, has mutagenic and genotoxic effects on biological systems, while $\mathrm{Cr}(\mathrm{III})$, in traces, is essential for proper functioning of lipid, glucose and protein metabolism in mammalians (Metze et al., 2003). However, the maximum allowable concentration of total $\mathrm{Cr}$ for agricultural soil in Hungary is $75 \mathrm{mg} / \mathrm{kg}$ (KvVM-EüM-FVM common order, 2009). Chromium mining was estimated to be $3.75 \times 10^{6}$ tons worldwide in 1997 (Kabata-Pendias, 2001). Normally, the Cr concentration in soil derived from mafic and volcanic rocks is larger (Kabata-Pendias, 2001). The Cr content of surface soil is known to be increased due to various anthropogenic sources (e.g., electroplating sludge, $\mathrm{Cr}$ pigment and tannery wastes) and municipal sewage sludge. The $\mathrm{Cr}$ added to soils is usually accumulated at its top layer (Kabata-Pendias, 2001). A fairly high $\mathrm{Cr}$ accumulation rate for surface soil layers of sludged farmland ranging from 214 to $727 \mathrm{mg} / \mathrm{kg}$ was reported (Kabata-Pendias, 2001). Surface soils contaminated with Cr were found in the proximity of smelter heaps, where its concentration exceeded 10,000 mg/kg (Kabata Pendias, 2001). Surface soil from the reclaimed land in Japan contained up to $4560 \mathrm{mg} / \mathrm{kg} \mathrm{Cr}$ (VI) per dry weight, despite earlier reduction of $\mathrm{Cr}(\mathrm{VI})$ to $\mathrm{Cr}(\mathrm{III})$ with $\mathrm{Fe}(\mathrm{II})$ in the surface layer of the slag (Asami, 1988).

The predominant $\mathrm{Cr}(\mathrm{VI})$ species dissolved in natural waters (i.e., $\mathrm{CrO}_{4}{ }^{2-}, \mathrm{HCrO}_{4}^{-}$) can be quite readily reduced to $\mathrm{Cr}(\mathrm{III})$ in the presence of electron donor compounds, like organic matter and inorganic compounds present in their reduced form (Stollenwerk and Grove, 1985). Dissolved Fe(II), minerals containing Fe(II), sulfides, and organic matter (Kotas and Stasicka, 2000; Wielinga et al., 2001) are mainly responsible for this type of reduction in the 
environment. According to studies involving reaction kinetics, Fe(II) and dissolved sulfides probably dominate the reduction of $\mathrm{CrO}_{4}{ }^{2-}$ to $\mathrm{Cr}$ (III) (Fendorf et al., 2001; Wielinga et al., 2001). In return, dissolved oxygen can oxidize $\operatorname{Cr}(\mathrm{III})$ into $\mathrm{Cr}(\mathrm{VI})$ (Eary and Rai, 1987; Nakayama et al., 1981). However, laboratory studies indicate that this can be a relatively slow process, requiring several months (Palmer and Wittbrodt, 1990), but taking place only in slightly acidic or basic media (Eary and Rai, 1987). These slow kinetics enable Cr(III) to be involved in other chemical reactions (sorption or co-precipitation) that are much faster (IETEG, 2005). Thus, Cr(III) is the most commonly occurring species in soil. Nevertheless, $\mathrm{Cr}$ is an element of low mobility, especially under moderately oxidizing and reducing conditions and near-neutral $\mathrm{pH}$. In soil, the behavior of $\mathrm{Cr}$ is governed by $\mathrm{pH}$, groundwater redox potential (Eh) and presence of organic matter (Oliveira, 2012; Caporale and Violante, 2016). Adsorption of chromium(VI) onto clay decreases with increasing $\mathrm{pH}$, and $\mathrm{Cr}(\mathrm{III})$ adsorption increases with increasing $\mathrm{pH}$ due to formation of hydroxo complexes (e.g., $\mathrm{CrOH}^{2+}$ and $\mathrm{Cr}(\mathrm{OH})_{2}{ }^{+}$between $\mathrm{pH} 5$ and 9). Chromium(III) readily substitutes for Fe(III) in minerals, and co-precipitates with $\mathrm{Fe}(\mathrm{III})$ as insoluble $\mathrm{Cr}(\mathrm{OH})_{3}$ at high $\mathrm{pH}$ values.

Detoxification studies of soils contaminated with toxic elements are currently of great importance (Bezuglova et al., 2018; Pukalchik et al., 2018). However, toxic elements cannot easily be eliminated from the contaminated soils. Therefore, mobility reduction of these elements using physical and chemical methods is an alternative for stabilization of inorganic contaminants in soil. In situ metal stabilization by amendments with coal fly ash, green waste compost, etc. has been demonstrated as an appealing low-cost remediation strategy for contaminated soils (Tsang et al., 2014; Wang et al., 2018). So far, several stabilization mechanisms have been proposed in the literature, such as: (i) adsorption (e.g., humic substances, Fe(III)-oxyhydroxides); (ii) complexation (e.g., humic substances, EDTA); (iii) precipitation (e.g., phosphates) (Klučaková and Omelka, 2004; Dong, et al., 2008; Janoš, et 
al., 2010). Soil components such as phyllosilicates, soil organic matter, carbonates, microorganisms, organo-mineral complexes, as well as soil $\mathrm{pH}$, nature of sorbents, redox reactions, and the presence of foreign ions also play an important role in binding ions (Caporale and Violante, 2016).

There is an increasing need for the determination of plant-available trace elements, especially those essential to plants, animals and humans. Application of a universal extractant for the simultaneous determination of metallic micronutrients available to plants would be ideal. Ethylene diamine tetraacetate (EDTA) has a high capability of forming metal complexes with cations allowing the quantitative determination of about 70 elements of the periodic table of elements including indirect and displacement volumetric methods (Skoog et al., 1992). Thus, combination of chemical stabilization with phytostabilization may be considered in the remediation of soils diffusely contaminated with toxic elements (Adriano, 2001).

Lignite, often referred to as brown coal, is the lowest rank of coal, produced under reductive conditions by the decomposition of biomass. It has a complex and heterogeneous 3D-structure consisting of amorphous polymers containing double- or triple-substituted aromatic rings (Schobert, 1995; Robles et al., 2017). Lignite is characterized by its high humic acid and fulvic acid content. Thus, these acids are capable primarily of immobilizing metals by means of complex formation or adsorption for di- and trivalent metals (Martyniuk and Wieckowska, 2003; Clemente and Bernal, 2006). Humic acids also stimulate plant growth and enhance soil nutrients storage (Fitz and Wenzel, 2002). So far, only a few studies focused on the application of this cheap sorbent for stabilization of toxic elements in soils (Klučaková and Omelka, 2004; Dong et al., 2008; Janoš et al., 2009; Arslan et al., 2010, Zhao et al., 2016). 
According to our previous investigation (Uzinger et al., 2014), lignite has been proven to be a cheap material suitable for the stabilization of some toxic metals in acidic sandy soils. To our best knowledge, the effect of different lignite size fractions to maximize the stabilization rate of toxic metals has not yet been studied. Therefore, the primary objective of the present work was to choose trivalent $\mathrm{Cr}$, considered as being essential only in traces and to explore the stabilization capacity of lignite added in different particle size ranges to the previously investigated acidic soil. Another objective was to extend the investigation on alkaline sandy soil matrix too. Assessment of stabilization and phytoavailability was studied by applying fit-for-purpose soil leaching tests.

\section{Experimental}

\subsection{Materials and reagents}

Throughout the experiments, the ultra-pure water of $18 \mathrm{M} \Omega \mathrm{cm}$ resistivity was taken from an ELGA Purelab Option-R7 unit (ELGA LabWater/VWS Ltd., High Wycombe, UK) and applied for the sample preparations and dilutions. Concentrated (conc.) ammonia, conc. $\mathrm{HNO}_{3}$, glacial acetic acid and conc. $\mathrm{HCl}$ were of Suprapur ${ }^{\circledR}$ (Merck, Darmstadt, Germany) quality. For phytoavailability studies, analytical grade disodium salt of EDTA (Scharlau Srl., Barcelona, Spain) was used. The Cr(III) stock solution was prepared from analytical grade chromium(III) nitrate nonahydrate, purchased from Sigma-Aldrich (Budapest, Hungary). For calibration, $1 \mathrm{~g} / \mathrm{L}$ acidic $\mathrm{Cr}(\mathrm{III})$ and $\mathrm{In}$ (used as internal standard) stock solutions (Merck) were used after appropriate dilutions. For the total-reflection X-ray fluorescence (TXRF) analysis, $1 \mathrm{~g} / \mathrm{L}$ acidic Y stock solution was also purchased from Merck. All standard solutions were prepared daily from stock solutions via appropriate dilutions in polypropylene (PP) 
Falcon ${ }^{\circledR}$ centrifuge tubes (Fisher Scientific, Waltham, MA, USA). The final $\mathrm{HNO}_{3}$ concentration of each sample solution was set to $5 \%(\mathrm{v} / \mathrm{v})$. Before sampling, the $50-\mathrm{mL}$ centrifuge tubes were soaked in $20 \%(\mathrm{v} / \mathrm{v}) \mathrm{HNO}_{3}$ for several days and then rinsed with deionized water. For the TXRF measurements, the quartz carrier plates were hydrophobized with silicone in isopropanol purchased from SERVA Electrophoresis GmbH (Heidelberg, Germany).

\subsection{Soil incubation treatments}

In the present study, an acidic and a calcareous sandy soil sampled from two Hungarian settlements, i.e., Nyírlugos $\left(47^{\circ} 43^{`} \mathrm{~N}, 22^{\circ} 00^{`} \mathrm{E}\right)$ and Örbottyán $\left(47^{\circ} 40^{`} \mathrm{~N}, 19^{\circ} 14^{`} \mathrm{E}\right)$ each sieved to $<2 \mathrm{~mm}$, respectively, were used. Lignite originating from the mines of Visonta, Hungary was size-fractionated in three particle ranges (i.e., $<0.5 \mathrm{~mm}, 0.5-1.0 \mathrm{~mm}$ and $1.0-2.0 \mathrm{~mm}$ ) by sieving. Then, each was added to the soil samples in a dose of $5 \%$ by weight. The physicochemical characterization of the studied soil and lignite samples is listed in Table 1. The soils were artificially contaminated with $375 \mathrm{mg} / \mathrm{kg}$ of $\mathrm{Cr}(\mathrm{III})$. The acidic and calcareous air-dry soil samples were homogenized and amounts of each $1 \mathrm{~kg}$ were placed in nonperforated, polypropylene (PP) round pots (height: $22 \mathrm{~cm}$; diameter: $12 \mathrm{~cm}$ ). Appropriate aliquots of a $\mathrm{Cr}(\mathrm{III})$ stock solution prepared by dissolving $\mathrm{Cr}\left(\mathrm{NO}_{3}\right)_{3} \cdot 9 \mathrm{H}_{2} \mathrm{O}$ and lignite were added simultaneously to the soil and thoroughly mixed. Then, each PP pot was covered with tinfoil. Moreover, blank $(n=12)$ and control $(n=6)$ soil samples were prepared too, each in triplicate. The control soil samples contained only $\mathrm{Cr}(\mathrm{III})$ in $375 \mathrm{mg} / \mathrm{kg}$ concentration. Blank samples contained either the soil itself or also lignite in three different size fractions. For each type of treatment three individual samples were considered. Thus, in total, 48 samples were subjected to further leaching tests. The incubation of samples under controlled temperature 
(kept at $21{ }^{\circ} \mathrm{C}$ ) and moisture content (65\% of field water capacity, monitored weekly) lasted for eight weeks. All experimental parameters were chosen based on a multi-factorial model design (Uzinger et al., 2014).

\subsection{Soil extraction procedures}

\subsubsection{Modified leaching procedure for BCR soil}

For assessment of the elemental stabilization, a modified Community Bureau of Reference, (BCR), European Commission, soil leaching procedure (Rauret et al., 2000) consisting of two steps was applied as summarized in Figure 1. Briefly, extraction of the water-soluble and carbonaceous fraction was achieved together with $0.11 \mathrm{~mol} / \mathrm{L}$ acetic acid solution. This step was followed by extraction of the fraction bound to amorphous oxides of $\mathrm{Fe}(\mathrm{III}) / \mathrm{Mn}(\mathrm{IV})$ with the assistance of $0.5 \mathrm{~mol} / \mathrm{L}$ hydroxylamine-hydrochloride at $\mathrm{pH} 2$. For leaching, the sample mass and extractant volume ratio was set to a ratio of 1-to-40 in the case of both leaching agents. Samples were shaken for $16 \mathrm{~h}$ at $30 \mathrm{rpm}$ by using an end-over-end shaker (IKA® Works Inc., Staufen, Germany). After extraction, the supernatant was separated from the samples by centrifugation at $4500 \mathrm{rpm}$ for 15 min performed in a tabletop centrifuge (Hermle Labortechnik GmbH, Wehingen, Germany). Finally, microwave (MW)-assisted digestion of the leachate residues with aqua regia was applied to obtain the pseudo-total fraction (for details see also Section 2.4.).

\subsubsection{Phytoavailability experiments}


The phytoavailable fraction of the samples was prepared according to the procedure recommended by Lakanen and Erviö (1971). Briefly, soil samples were extracted for $1 \mathrm{~h}$ with $0.02 \mathrm{~mol} / \mathrm{L}$ EDTA solution of $\mathrm{pH} 4.65$ (Figure 1). This $\mathrm{pH}$ value was set with conc. ammonia by using an OP-212/2 pH-meter (Radelkis Ltd., Budapest, Hungary). The soil mass and extractant volume ratio was set to a ratio of 1-to-10. After completion of the extraction, centrifugation was applied as described in Section 2.3.1. Finally, the same MW-assisted digestion method with aqua regia was applied for the leachate residues as described in Section 2.4 .

2.4. Inductively coupled plasma mass spectrometric methods

Prior to elemental analysis, the initial samples as well as the leachate residues were subjected to MW-assisted aqua regia digestion performed using an Ethos Plus 1 equipment (Milestone S.r.1., Sorisole, Italy) according to the slightly modified EU Standard EN 13346 (2000). Briefly, each $1.0 \mathrm{~g}$ of the homogenized samples was transferred into 100-mL PTFE digestion vessels $(\mathrm{n}=5)$. Then, $8 \mathrm{~mL}$ of aqua regia was added to the samples. The steps of the MWassisted digestion program were as follows: $500 \mathrm{~W}$ for $4 \mathrm{~min}$; $750 \mathrm{~W}$ for another $5 \mathrm{~min}$ and finally, $800 \mathrm{~W}$ for another $12 \mathrm{~min}$. The upper temperature limit was $170{ }^{\circ} \mathrm{C}$. After the digestion was completed, the vessels were cooled down and the digested samples were decanted into PP tubes and diluted (1000-fold) for $\mathrm{HNO}_{3}$ concentration to be set as $5 \%(\mathrm{v} / \mathrm{v})$. Concentrations of $\mathrm{Cr}, \mathrm{Mn}$ and Fe were determined by inductively coupled plasma sector field mass spectrometry (ICP-SF-MS) performed on an Element 2 equipment (Thermo-Fisher Scientific, Bremen, Germany). The acetic acid, hydroxylamine and EDTA leachates were analyzed directly after proper dilution. For these determinations, $50 \mu \mathrm{g} / \mathrm{L}$ In was used as 
internal standard. The optimized operating conditions for the ICP-SF-MS measurements and the monitored isotopes are listed in Table 2.

2.5. Total-reflection X-ray fluorescence analysis for quality assurance

The TXRF measurements were carried out on an ATOMIKA Model TXRF 8030C spectrometer (ATOMIKA Instruments $\mathrm{GmbH}$, Oberschleißheim, Germany), equipped with a Mo-W mixed anode X-ray tube operating at $50 \mathrm{kV}$ and $47 \mathrm{~mA}$. For excitation, the $\mathrm{K}_{\alpha}$ line of Mo was used. The energy calibration of the instrument was performed prior to analysis, and periodically during the measurements with $100 \mathrm{ng}$ of $\mathrm{Ni}$, applied as reference standard. Attenuation of the background intensity was achieved by using a double layer $\mathrm{ZrO}_{2}$ filter. The detection of fluorescent photons was performed with an energy dispersive $\mathrm{Si}(\mathrm{Li})$ semiconductor detector fitted with a $80 \mathrm{~mm}^{2}$ entrance window, continuously cooled with liquid nitrogen. Signal processing was done by a recording unit consisting of a (pre)amplifier, an analogue-digital converter and a multichannel analyzer.

For hydrophobization, $10 \mu \mathrm{L}$ of silicone solution in isopropyl alcohol was dropped onto the surface of the quartz carriers; then, they were dried at $110^{\circ} \mathrm{C}$ on a hot plate. Two point five $\mu \mathrm{L}$ of the samples, containing $100 \mu \mathrm{g} / \mathrm{L} \mathrm{Y}$ as internal standard were dropped onto the hydrophobized carriers. After drying the samples at $80^{\circ} \mathrm{C}$, they were placed into the TXRF equipment. The signal acquisition time was $100 \mathrm{~s}$ and $1000 \mathrm{~s}$ for the energy calibration and the analyses, respectively. For the analyses, the signal of $\mathrm{Cr} \mathrm{K}_{\alpha}$ line at $5.415 \mathrm{eV}$ was recorded.

\subsection{Determination of lignite porosity and point of zero charge}


Nitrogen physisorption measurements were performed at $-196{ }^{\circ} \mathrm{C}$ using an automated volumetric adsorption analyzer (Thermo Scientific Surfer gas adsorption porosimeter, Bremen, Germany). Before use, lignite samples were degassed under high vacuum $\left(<10^{-6}\right.$ mbar) at $200{ }^{\circ} \mathrm{C}$ for $2 \mathrm{~h}$. Specific surface area was calculated by the BET equation at $0.01-0.2$ relative pressure. Before each test, the coal sample of $1-2 \mathrm{~g}$ in weight was degassed for $12 \mathrm{~h}$ at $383 \mathrm{~K}$ to remove air, water and other volatile matters. At each pressure set-point, the sorption equilibrium was established automatically when the pressure stabilized for $30 \mathrm{~s}$. The absolute pressure tolerance was set as $5 \mathrm{mmHg}$ (6.66 mbar). Pore size distribution was evaluated from the adsorption branch, according to the BJH method. Micropore volume was calculated by the $\alpha_{\mathrm{s}}$ plot method. The mesopore volume was calculated as difference of the total pore and micropore volumes.

Scanning electron microscopy (SEM) studies were performed on a model Quanta 3D apparatus (FEI, USA) equipped with secondary Everhart-Thornley detector and backscattered electron detector together with silicon drift energy dispersive detector. For the measurements, $20 \mathrm{kV}$ accelerating voltage, $15-480 \mathrm{pA}$ probe current and $50 \mathrm{~s}$ as lifetime were used.

The point of zero charge (PZC) of the different lignite samples was determined in 25 $\mathrm{mL}$ of $0.001,0.01$ and $0.1 \mathrm{~mol} / \mathrm{L} \mathrm{NaCl}$ solutions by applying the $\mathrm{pH}$ drift method $c f$. Varga et al. (2019). Briefly, the $\mathrm{pH}$ of the samples was adjusted between 1 and $12(\mathrm{n}=10)$ using proper amounts of $\mathrm{NaOH}$ or $\mathrm{HCl}$ solutions and the initial $\mathrm{pH}$ of the solutions was recorded. Then, lignite was added to these solutions in an identical application rate to that one used for the soil incubation (i.e., $5 \%$ by weight). After $24 \mathrm{~h}$ of shaking at $30 \mathrm{rpm}$ by using the aforementioned IKA ${ }^{\circledR}$ end-over-end shaker, the suspensions were filtered through Whatman microfiber glass filters (diameter: $2 \mathrm{~mm}$ ) by using a 12-port Visiprep ${ }^{\circledR}$ solid phase extraction vacuum manifold (Sigma-Aldrich). The PZC values were determined by plotting the $\Delta \mathrm{pH}$ (final $\mathrm{pH}-$ initial $\mathrm{pH}$ ) 
vs. initial $\mathrm{pH}$. The point of intersection of the resulting curve with the abscissa (at $\Delta \mathrm{pH}=0$ ), gave the PZC values.

\section{Results and discussion}

\subsection{General considerations}

The vast majority of ion exchangers of plant origin act as cation-exchangers due to the ubiquitous presence of carboxylic and hydroxyl groups in them. In our previous work, we demonstrated that lignite was capable of immobilizing heavy metal ions such as $\mathrm{Cr}(\mathrm{III})$, due to its cation-exchange binding sites (Uzinger et al., 2014). Chromium was applied in its predominant form in soils under oxidizing conditions, thus $\mathrm{Cr}(\mathrm{III})$. The $\Sigma \mathrm{Cr}$ concentration of soils should not exceed $75 \mathrm{mg} / \mathrm{kg}$ according to the Hungarian legislation in force (KvVMEüM-FVM common order, 2009). The concentration of $\mathrm{Cr}$ (III) in artificially contaminated soils, as well as the dosage value of lignite was chosen according to previous findings (Uzinger et al., 2014). The rationale behind choosing a fairly high $\mathrm{Cr}(\mathrm{III})$ concentration was to evaluate the response of the soil system to such a provocative but realistic dose.

As it has been reported, accumulation of elements in soil may depend on the grain size of lignite (Uçurum, 2009). Lignite was sieved through different mesh size sieves, i.e., $<0.5 \mathrm{~mm}$, 0.5-1.0 $\mathrm{mm}$ and $1.0-2.0 \mathrm{~mm}$, to further explore this feature, because it is important to enhance the transfer of $\mathrm{Cr}$ (III) between the soil and lignite particles, as much as possible. At the same time, dispersibility is also an important factor for such applications, with monodispersed grains often being the most desirable. Moreover, two relatively simple soil systems were applied that mainly differed in their $\mathrm{pH}$ (Table 1) due to their calcium carbonate content. 
For studying efficiency of stabilization, fit-for-purpose modified BCR leaching steps were applied. Thus, to characterize the $\mathrm{Cr}$ bound to water-soluble and carbonaceous fractions, extraction with acetic acid was obviously selected for the present work. Soil leaching with an oxidizing agent was not performed as the formed $\mathrm{Cr}(\mathrm{VI})$ would have been reduced to $\mathrm{Cr}(\mathrm{III})$ in the presence of organic matter even though in traces. For the evaluation of phytoavailability, extraction with EDTA, as a broad-spectrum complexing agent was also applied.

\subsection{Porosity and point of zero charge characteristics of lignite samples}

Porosity of the different lignite fractions used in the present study has been proven by means of SEM measurements (Figure 2). Porosity of lignite can be expressed by the pore volume, pore size distribution, mean pore diameter, and micro- or meso-pore surface area (Stavropoulos et al., 1993). Pore accessibility of microporous materials is limited, while macroporous materials show low selectivity for different contaminants. That is why, mesoporous materials can represent a compromise. For mesoporosity, the characterization of raw lignite, by studying $\mathrm{N}_{2}$ adsorption-desorption is a common procedure. The adsorbed volume of nitrogen on raw lignite was observed to be low (Figure 3), which is in agreement with literature (Stavropoulos et al., 1993). All isotherms showed an H3 hysteresis loop. The specific surface area of raw lignite calculated by the BET method did not exceed $5 \mathrm{~cm}^{2} / \mathrm{g}$. The total pore volume was below $<0.021 \mathrm{~cm}^{3} / \mathrm{g}$. However, this volume increased by 2.2 and 3.7 times by decreasing the lignite particle size from $1.0-2.0 \mathrm{~mm}$ and $0.5-1.0 \mathrm{~mm}$ down to $<0.5 \mathrm{~mm}$, respectively (Table 3). The specific surface area was similar for the $<0.5 \mathrm{~mm}$ and 0.5-1.0 mm lignite fractions. However, the lignite fraction with the largest particle size had again the lowest surface area. This means that grinding modified the porosity of the different 
lignite samples. Thus, the surface area and the pore volume increased several times by decreasing the particle size. However, surface area did not increase considerably below 1.0 $\mathrm{mm}$ grain size. It can be concluded that grinding of lignite below $1.0 \mathrm{~mm}$ is unnecessary from the point of view of the present study.

The zero surface charge characteristics of the three different lignite size fractions applying it in the same dose as for the incubation experiments (i.e., 5.0\% by weight) has been proven to be very similar. The results obtained for all three lignite fractions in a $0.01 \mathrm{~mol} / \mathrm{L}$ $\mathrm{NaCl}$ solution are shown in Figure 4. Thus, two PZC values could be determined. No considerable shift was observed in the PZC values by varying the ionic strength of the electrolyte background (i.e., in the range of $0.001-0.1 \mathrm{~mol} / \mathrm{L} \mathrm{NaCl}$ ). Both PZC values were observed in the acidic region owing to the humic acid and fulvic acid content of lignite. This finding is in good agreement with previous data reported on Lakhra-coal (Khan and Sarwar, 2007), lignite particles of $0.1-0.3 \mathrm{~mm}$ size mined in India applied for removal of $\mathrm{Pb}$ (II) ions (Rao et al., 2011) and activated coal originating from the Thar coalfield in Pakistan (Khan and Bhutto, 2012). In the present study, one PZC was determined at $\mathrm{pH} 1.5$ and a second one at $\mathrm{pH} \approx 4.5$. From the environmental point of view, only the second $\mathrm{PZC}$ value is relevant. Thus, at $\mathrm{pH}$ above this second $\mathrm{PZC}$, the surface of the lignite is negatively charged enhancing adsorption of $\mathrm{Cr}(\mathrm{III})$ ions, as well as its positively charged hydroxo complexes formed at slightly basic $\mathrm{pH}$ values.

\subsection{Analytical capabilities and quality assurance of the $\mathrm{Cr}$ determination}

The extraction leachates were analyzed for $\mathrm{Cr}$ by ICP-SF-MS. Moreover, the elemental concentration in the aqua regia extracts as well as in the pseudo-total fractions were also determined by ICP-SF-MS after MW-assisted digestion with aqua regia $c f$. EU Standard EN 
13346. After subtraction of the blank values, proper mass balances could be established between the sum of $\mathrm{Cr}$ contents of the different fractions and pseudo-total elemental ones. The set-up of the mass balance demonstrated that $\mathrm{Cr}$ could be effectively extracted from the artificially contaminated soils without application of HF.

Besides this technical requirement, precision of the results expressed as the relative standard deviation of the mean $\mathrm{Cr}$ concentration calculated from the results of three replicates were generally less than $20 \%$ for each sample matrix.

Accuracy was checked by analyzing each representative sample matrix by an alternative instrumental analytical technique. In our case, TXRF was chosen as being a multielement and cost-effective instrumental approach with excellent limits of detection for Cr. Due to the relatively high application dose of $\mathrm{Cr}$ in soil, the layer thickness of the dry residues on the TXRF sample carriers due to presence of the organic leaching agents could easily be minimized by applying appropriate dilution of the sample solutions. The total $\mathrm{Cr}$ concentrations in the same soil sample matrices in the case of the $0.5-1.0 \mathrm{~mm}$ lignite grain size fraction determined by means of ICP-SF-MS and TXRF can be seen in Table 4 . The smallest deviation $(<10 \%)$ of the concentrations obtained for $\mathrm{Cr}$ by the two different analytical techniques were obviously observed for samples subjected to MW-assisted digestion prior to elemental analysis. Comparable deviation values were obtained for the EDTA containing fractions diluted 1000-fold, prior to TXRF analysis. Larger variations in $\mathrm{Cr}$ concentrations reaching in some cases as high as $30 \%$ were observed for the one hundred-fold diluted acetate- and hydroxylamine-hydrochloride-based samples. These variations did not considerably depend on the elemental concentration, but rather on the organic content of the investigated sample (Table 4). However, as it was mentioned, TXRF is a cost-effective multielement analytical technique and, hence, it can be used instead of CRM analysis without even performing MW-assisted acid digestion of the leachates. 
As a recovery test, the concentration of $\mathrm{Cr}$ in the different leachates was summed and related to the pseudo-total $\mathrm{Cr}$ concentration (Table 5). As expected, the sum of the $\mathrm{Cr}$ concentration in the different fractions was generally lower than the corresponding pseudototal concentration. Nevertheless, the deviation, with few exceptions, did not exceed $+20 \%$ (Table 5).

\subsection{Stabilization of $\mathrm{Cr}$ (III) in soils containing lignite with different particle sizes}

Approximately $90 \%$ of the pseudo-total Cr was immobilized by the calcareous sandy soil itself due to its basic $\mathrm{pH}$ (Figure 5a). Distribution of $\mathrm{Cr}$ among the different fractions showed a similar pattern independently of the treatment type and the presence or absence of lignite (Figure 5a). Moreover, the lignite particle size had little influence on $\mathrm{Cr}$ stabilization (Figure 5a). The abundance of $\mathrm{Cr}$ in the acetic acid and hydroxylamine leachates was generally less than $2 \%$ and $5 \%$, when the calcareous sandy soil had been contaminated with $\mathrm{Cr}$ (III) (Figure 5a). It is likely that positively charged $\mathrm{Cr}$ (III) hydroxo complex species were formed during the interaction of $\mathrm{Cr}$ with the calcareous soil matrix. Since the environmentally relevant PZC value was cca. 4.5, adsorption of $\mathrm{CrOH}^{2+}$ and $\mathrm{Cr}(\mathrm{OH})_{2}{ }^{+}$species onto the surface of the applied lignite between $\mathrm{pH}=5$ and 9 could not be neglected. However, $\mathrm{CrOH}^{2+}$ and $\mathrm{Cr}(\mathrm{OH})_{2}{ }^{+}$species formed in the aforementioned $\mathrm{pH}$ interval possess low water solubility (Rai et al., 1987). Due to the immobilization of the $\mathrm{Cr}(\mathrm{III})$ in form of hydroxo species formed in the calcareous soil, it is presumable that $\mathrm{Cr}$ does not reach the lignite particles.

On average, a 20\% lower stabilization rate was recorded for acidic control soil, compared to that obtained for the calcareous one without addition of lignite due to the hydroxylamine extraction applied (Figure 5b). The $\mathrm{Cr}$ content of the hydroxylamine leachate increased by about $10-20 \%$ upon addition of lignite. Nevertheless, addition of lignite contributed to the 
reduction of $\mathrm{Cr}$ mobility in the acetic acid leachates presumably due to stabilization through binding to its cation-exchange sites. This finding was corroborated by the fact that the $\mathrm{pH}$ of the acidic soil used is 5.0 and the environmentally relevant PZC value of the lignite samples was at $\mathrm{pH} \approx 4.5$. Nevertheless, the stabilization rate of $\mathrm{Cr}$ in acidic soil was again not influenced by the lignite size fractions. In the case of the acidic soil, hydrolysis of $\mathrm{Cr}(\mathrm{III})$ is less pronounced, and hence its mobility increases. Similar findings by Pukalchik et al. (2018) suggest that solution $\mathrm{pH}$ values can significantly affect metal species distribution and, as a result, metal sorption in soil. Changes in $\mathrm{pH}$ influence directly humic products, because of their functional groups, such as carboxyl, phenolic, and amino, are pH-dependent (Pukalchik et al., 2018), which may result in Fe(III) reduction to Fe(II) (Mejia et al., 2016).

Upon addition of lignite to the acidic soil artificially contaminated with $\mathrm{Cr}(\mathrm{III})$, the $\mathrm{Cr}$ availability decreased by about $10 \%$ in the hydroxylamine leachates independently of the lignite particle size. The hydroxylamine hydrochloride solution $(\mathrm{pH} 2)$ reduces most of $\mathrm{Fe}(\mathrm{III}) / \mathrm{Mn}(\mathrm{IV})$. The mean concentration of $\mathrm{Fe}$ and $\mathrm{Mn}$ in the investigated soils can be seen in Table 1. Iron was released in less than $1 \%$ after the acetic acid extraction. However, the Fe abundance in the samples after leaching with hydroxylamine was about $5 \%$ of the pseudototal Fe independently of the soil type and treatments. At the same time, the concentration of $\mathrm{Mn}$ in different leachates fell under the limit of quantitation after leaching and MW-assisted acid digestion.

3.5. Assessment of phytoavailability in soils artificially contaminated with $\mathrm{Cr}$ (III)

Concerning assessment of the phytoavailability of the investigated elements, EDTA is widely used extractant. Nevertheless, complexation of $\mathrm{Cr}(\mathrm{III})$ is hindered due to the thermodynamic stability and inertness of its aqua complex. However, the use of a single extractant is always 
advantageous from the view point of measurement uncertainty. According to the present results, the phytoavailable $\mathrm{Cr}$ fraction estimated by leaching of the calcareous soil with EDTA was about $10-20 \%$ of the pseudo-total $\mathrm{Cr}$ independently of the applied treatment (Figure 6a). Again, the soil alkalinity (i.e., $\mathrm{pH} \approx 8$ ) and the cation exchange capacity of lignite immobilize $\mathrm{Cr}(\mathrm{III})$ through hydrolysis and subsequent formation of low water solubility positively charged hydroxo complexes, respectively.

In the case of the acidic soil itself, approximately $20-25 \%$ of the pseudo-total $\mathrm{Cr}$ concentration was leached in the case of the control and $<0.5 \mathrm{~mm}$ lignite particle size, while the phytoavailable $\mathrm{Cr}$ fraction decreased to about half, when lignite particle size was $0.5-1.0$ $\mathrm{mm}$ and 1.0-2.0 mm (Figure 6b). According to our results, Mn could not be again quantitated in the case of EDTA extraction and about $2-3 \%$ of the pseudo-total Fe could be determined independently of the soil $\mathrm{pH}$ and treatment.

Assuming that the higher plants are capable of nutrient uptake by root surface acidification often accompanied by $\mathrm{H}^{+}$-mediated reduction, leaching with hydroxylamine can be considered to a certain extent suitable for estimation of the phytoavailable fraction of $\mathrm{Cr}$, especially, because EDTA is not capable of complexing $\mathrm{Cr}$ (III) at ambient temperatures, due to kinetic hindrance. Therefore, it seems reasonable to compare the percent of $\mathrm{Cr}$ in EDTA and hydroxylamine leachates. The hydroxylamine and EDTA leaching gave similar results for both soils and lignite addition. Thus, the stabilization patterns of $\mathrm{Cr}$ as a function of the lignite particle sizes were in agreement. The only difference was that the $\mathrm{Cr}$ percent in the hydroxylamine leachate of the calcareous soil was about twice less than in the corresponding acidic soil leachates. The EDTA seems to liberate $\mathrm{Cr}$ indirectly through complexation of other metal ions. In return, hydroxylamine liberates $\mathrm{Cr}(\mathrm{III})$ associated to amorphous $\mathrm{Fe}(\mathrm{III}) / \mathrm{Mn}(\mathrm{IV})$ minerals through reduction of these two latter elements. Due to the low $\mathrm{pH}$ of this reducing agent ( $\mathrm{pH}$ 2), the relatively mobile $\mathrm{Cr}$ in acidic soil can be retained by the lignite particles. 


\section{Conclusions}

Soil $\mathrm{pH}$ appears to be a determining factor in $\mathrm{Cr}$ (III) (im)mobilization. Calcareous soil immobilizes $\mathrm{Cr}$ rendering it unavailable for stabilization by lignite. Application of lignite enhances stabilization of $\mathrm{Cr}(\mathrm{III})$ only in acidic soil. However, the lignite grain size applied in the range of $<0.5-2.0 \mathrm{~mm}$ in the present study did not provide any considerable additional gain on stabilization rates of $\mathrm{Cr}(\mathrm{III})$. Thus, $\mathrm{Cr}(\mathrm{III})$ stabilization was not influenced considerably by the surface area and pore volume of the applied three lignite fractions. Nevertheless, a similar grain size of lignite and soil has been proven to ensure the dispersibility needed by a heterogeneous matrix in order to enhance $\mathrm{Cr}$ (III) transfer from the contaminated soil to the lignite particles capable of stabilization.

\section{Acknowledgements}

The financial support of the Stiftung Aktion Österreich - Ungarn through grant No. 98 öu11 is hereby, gratefully acknowledged. The financial support of the National Research, Development and Innovation Office of Hungary through the bilateral Sino-Hungarian Scientific and Technological Cooperation under grant No. TET_2018-2.1.14-TÉT-CN-201800022 is warmly thanked. Timothy Anemana expresses his gratitude for the financial support ensured by the Stipendium Hungaricum $\mathrm{PhD}$ training program of the Tempus Foundation (Hungary). The help of Zoltán Dankházi and Márta Kerepesi-Lovász during the SEM and PZC measurements is, hereby, acknowledged, respectively.

Conflicts of Interest: The authors declare no conflict of interest. 


\section{References}

Adriano, D.C. 2001. Lead. In: Trace Elements in Terrestrial Environments: Biogeochemistry, Bioavailability and Risks of Metals, pp. 349-410 (Adriano, D.C., Ed), Springer-Verlag, New York.

Arslan, G., Edebali, S., and Pehlivan, E. 2010. Physical and chemical factors affecting the adsorption of $\mathrm{Cr}(\mathrm{VI})$ via humic acids extracted from brown coals, Desalination 255, 117-123. Asami, T. 1988. Soil pollution by metals from mining and smelting activities. In: Chemistry and Biology of Solid Waste, pp. 143-169 (Salomons, W., and Förstner, U., Eds), SpringerVerlag, Berlin.

Bezuglova, O.S., Gorbova, S.N., Tischenko, S.A., and Shimko, A.E. 2018. Use of brown coal as a detoxifier of soils contaminated with heavy metals, J. Geochem. Explor. 184, 232-238.

Caporale, A.G. and Violante, A. 2016. Chemical processes affecting the mobility of heavy metals and metalloids in soil environments. Curr. Pollut. Rep. 2, 15-27.

Clemente, R. and Bernal, M.P. 2006. Fractionation of heavy metals and distribution of organic carbon in two contaminated soils amended with humic acid. Chemosphere 64, 13641273.

Dong, L.H., Yang, J.S., Yuan, H.L., Wang, E.T., and Chen, W.X. 2008. Chemical characteristics and influences of two fractions of Chinese lignite humic acids on urease, Eur. J. Soil Biol. 44, 166-171.

Eary, L.E. and Rai, D. 1987. Kinetics of chromium (III) oxidation to chromium(VI) by reaction with manganese dioxide. Environ. Sci. Technol. 21, 1187-1193.

European Committee for Standardization EN 13346 (2000): Characterization of sludges Determination of trace elements and phosphorus - Aqua regia extraction methods. 
Fendorf, S., Wielinga, B.W., and Hansel, C.M. 2001. Chromium transformations in natural enviuronments: The role of biological and abiological processes in chromium(VI) reduction, Int. Geol. 42, 691-701.

Fitz, W.J. and Wenzel, W.W. 2002. Arsenic transformations in the soil/rhizosphere/plant system: fundamentals and potential application to phytoremediation. J. Biotechnol. 99, 259278.

IETEG - Independent Environmental Technical Evaluation Group 2005. Oxidation reduction of chromium. In: Chromium(VI) Handbook, pp. 172-180 (Guertin J., Jacobs J.A., and Avakian, C.P. Eds), CRC Press, Boca Raton.

Janoš, P., Hůla, V., Bradnová, P., Pilařová, V., and Šedlbauer, J. 2009. Reduction and stabilization of hexavalent chromium with coal- and humate-based sorbents, Chemosphere 75, $732-738$.

Janoš, P., Vávrová, J., Herzogová, L., and Pilařová, V. 2010. Effects of inorganic and organic amendments on the mobility (leachability) of heavy metals in contaminated soil: A sequential extraction study, Geoderma 159, 335-341.

Kabata-Pendias, A. 2001. Elements of Group VI. V. Chromium. In: Trace Elements in Soils and Plants, pp. 266-273 (Kabata-Pendias, A., Pendias, H. Eds.), CRC Press, Boca Raton.

Khan, M. and Sarwar, A. 2007. Determination of points of zero charge of natural and treated adsorbents. Surf. Rev. Lett. 14, 461-469.

Khan, M. and Bhuto, S. 2012. Preparation and characterization of activated carbon from lignite coal by chemical activation and its application for lead removal from wastewater. IJCEES 3, 28-39.

Klučaková, M. and Omelka, L. 2004. Sorption of metal ions on lignite and humic acids. Chem. Pap. 58, 170-175. 
Kotas, J. and Stasicka, Z. 2000. Chromium occurrence in the environment and methods of its speciation. Environ. Poll. 107, 263-283.

KvVM-EüM-FVM common order 6/2009. (IV. 14.) about the standard limits and measurement of contamination for the protection of underground water and geological medium. 2009. Magyar Közlöny 51, 14398-14414.

Lakanen, E. and Erviö, R. 1971. A comparison of eight extractants for the determination of plant available micronutrients in soils. Acta Agr. Fenn. 123, 223-232.

Martyniuk, H. and Wieckowska, J. 2003. Adsorption of metal ions on humic acids extracted from brown coals. Fuel Process. Technol. 84, 23-36.

Mejia, J., Roden, E.E., and Ginder-Vogel, M. 2016. Influence of oxygen and nitrate on Fe (Hydr)oxide mineral transformation and soil microbial communities during redox cycling, Environ. Sci. Technol. 50, 3580-3588.

Metze, D., Jakubowski, N., and Klockow, D. 2003. Speciation of chromium: Speciation of chromium in environment and food. In: Handbook of Elemental Speciation, pp. 120-135 (Cornelis, R., Caruso, J., Crews, H. and Heumann, K. Eds.), John Wiley \& Sons Ltd., Chichester.

Oliveira, H. 2012. Chromium as an environmental pollutant: Insights on induced plant toxicity. J. Bot. 2012, e375843.

Nakayama, E., Kuwamoto, T., Tsurubo, S., Tokoro, H., and Fujinaga, T. 1981. Chemical speciation of chromium in sea water 1 . Effect of naturally occurring organic materials on the complex formation of chromium(III), Analyt. Chim. Acta. 130, 289-294.

Palmer, C.D. and Wittbrodt, P.R. 1991. Processes affecting the remediation of chromiumcontaminated sites, Environ. Health Perspect. 92, 25-40. 
Pukalchik, M., Panova, M., Karpukhin, M., Yakimenko, O., Kydralieva, K., and Terekhova V. 2018. Using humic products as amendments to restore $\mathrm{Zn}$ and $\mathrm{Pb}$ polluted soil: A case study using rapid screening phytotest endpoint, J. Soils Sediments 18, 750-761.

Rai, D., Sass, B.M., and Moore, D.A. 1987. Chromium(III) hydrolysis constants and solubility of chromium(III) hydroxide, Inorg. Chem. 26, 345-349.

Rao, R., Khan, M., and Rehman, F., 2011. Batch and column studies for the removal of lead(II) ions from aqueous solution onto lignite, Adsorpt. Sci. Technol. 29, 83-98.

Rauret, G., López-Sánchez, J.-F., Sahuquillo, A., Barahona, E., Lachica, M., Ure, A.M., Davidson, C.M., Gomez, A., Lück, D., Bacon, J., Yli-Halla, M., Muntau, H., and Quevauviller, Ph. 2000. Application of a modified BCR sequential extraction (three-step) procedure for the determination of extractable trace metal contents in a sewage sludge amended soil reference material (CRM 483), complemented by a three-year stability study of acetic acid and EDTA extractable metal content, J. Environ. Monit. 2, 228-233.

Robles, I., Bustos, E., and Lakatos, J. 2017. Adsorption study of mercury on lignite in the presence of different anions, J. Environ. Manage. 186, 285-292.

Schobert, H.H. 1995. The organic structure of lignite. In: Coal Science and Technology 23Lignites of North America, pp. 79-138 (Schobert, H.H. Ed), Elsevier, Amsterdam.

Skoog, D.A., West, D.M., and Holler, F.J., Crouch, S.R. 1992. Complexation Reactions and Titrations. In: Fundamentals of Analytical Chemistry, pp. 458-482 (Skoog, D.A., West, D.M., and Holler, F.J. Eds.), Saunders College Publishing, Orlando.

Stavropoulos, G.G., Korili, S.A., and Sakellaropoulos, G.P. 1993. Porosity characteristics of lignite chars, Stud. Sci. Surf. Catal. 80, 599-605.

Stollenwerk, K.G. and Grove, D.B. 1985. Adsorption and desorption of hexavalent chromium in an alluvial aquifer near Telluride, Colorado. J. Environ. Qual. 14, 150-155. 
Tsang, D.C.W., Yip, A.C., Olds, W.E., and Weber, P.A. 2014. Arsenic and copper stabilisation in a contaminated soil by coal fly ash and green waste compost, Environ. Sci. Pollut. Res. 21, 10194-10204.

Uçurum, M. 2009. A study of removal of $\mathrm{Pb}$ heavy metal ions from aqueous solution using lignite and a new cheap adsorbent (lignite washing plant tailings). Fuel 88, 1460-1465.

Uzinger, N., Rékási, M., Draskovits, E., and Anton, A. 2014. Stabilization of Cr, $\mathrm{Pb}$ and Zn in soil using lignite, Soil Sediment. Contam. 23, 270-286.

Varga, M., ELAbadsa, M., Tatár, E., and Mihucz, V.G. 2019. Removal of selected pharmaceuticals from aqueous matrices with activated carbon under batch conditions, Microchem. J. 148, 661-672.

Wang, L., Chen, S.S., Sun, Y.-Q., Tsang, D.C.W., Yip, A.C.K., Ding, S., Hou, D., Baek, K., and Ok, Y.S. 2018. Efficacy and limitations of low-cost adsorbents for in-situ stabilization of contaminated marine sediment, J. Clean. Prod. 212, 420-427.

Wielinga, B., Mizuba, M., Hansel, C., and Fendorf, S. 2001. Iron promoted reduction of chromate by dissimilatory iron-reducing bacteria, Environ. Sci. Technol. 35, 522-527.

Zhao, T-T., Ge, W-Z., Yue, F., Wang, Y-X., Pedersen, C.M., Zeng, F-G., and Qiao, Y. 2016. Mechanism study of $\mathrm{Cr}(\mathrm{III})$ stabilization in the process of $\mathrm{Cr}(\mathrm{VI})$ removal by Huolinhe lignite, Fuel Process. Technol. 152, 375-380. 


\section{Figure captions}

Figure 1. Schematic diagram of the sample preparation steps and analysis performed on the investigated soil samples. BCR $=$ Community Bureau of Reference, European Commission.

Figure 2. Scanning electron microscopic image of a representative lignite particle in the $0.5-$ $1.0 \mathrm{~mm}$ at 250 -fold magnification, registered at $20 \mathrm{kV}$ and $60 \mathrm{pA}$.

Figure 3. Nitrogen gas adsorption-desorption isotherms of the studied lignite samples as a function of particle size: 1.0-2.0 $\mathrm{mm}$ (red); 0.5-1.0 $\mathrm{mm}$ (blue) and $<0.5 \mathrm{~mm}$ (green). Symbols of filled and empty circles were used to indicate adsorption and desorption isotherms, respectively.

Figure 4. Point of zero charge ( $\mathrm{PZC} \pm$ standard deviation) values $(\mathrm{n}=3)$ of lignite having $<0.5$ $\mathrm{mm}(\mathrm{a}) ; 0.5-1.0 \mathrm{~mm}(\mathrm{~b})$ and $1.0-2.0 \mathrm{~mm}$ (c) particle size ranges determined by the $\mathrm{pH}$ drift method. Data were connected with dashed lines for better visualization of the PZC values.

Figure 5. Chromium distribution (\%) among different leachates of calcareous (a) and acidic (b) sandy soils without lignite or containing 5.0\% lignite by weight and particle size ranges of $<0.5 \mathrm{~mm} ; 0.5-1.0 \mathrm{~mm}$ or $1.0-2.0 \mathrm{~mm}$ after eight weeks of incubation with $375 \mathrm{mg} / \mathrm{kg} \mathrm{Cr}$ (III). Residual percentage originated from individual measurements.

Figure 6. Chromium distribution (\%) between the EDTA leachates and extraction residue of calcareous (a) and acidic (b) sandy soils without lignite or containing 5.0\% lignite by weight and particle size ranges of $<0.5 \mathrm{~mm} ; 0.5-1.0 \mathrm{~mm}$ or $1.0-2.0 \mathrm{~mm}$ after eight weeks of incubation with $375 \mathrm{mg} / \mathrm{kg} \mathrm{Cr}(\mathrm{III})$. Residual percentage originates from individual measurements. 
Figures

Figure 1.

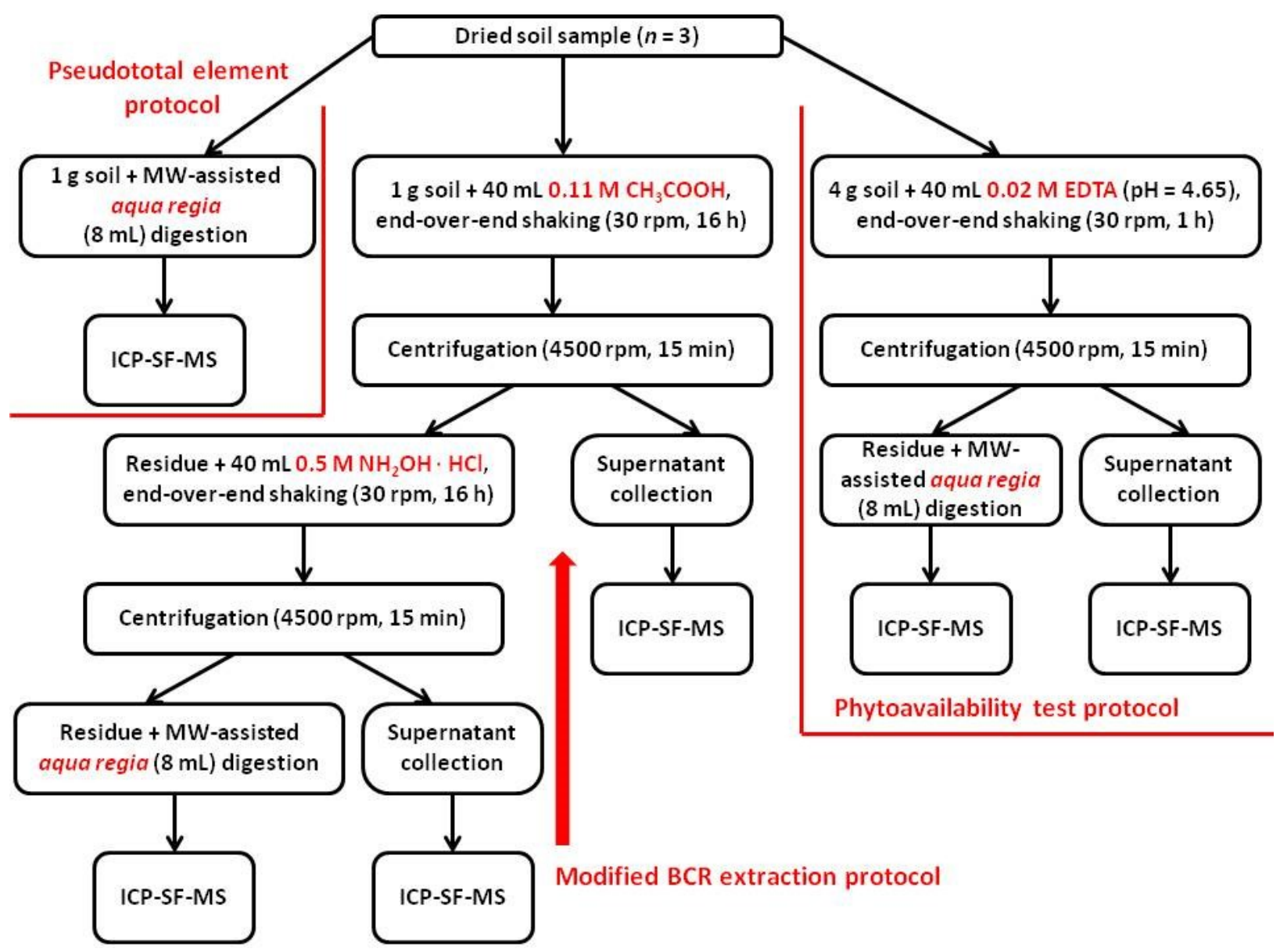


Figure 2.

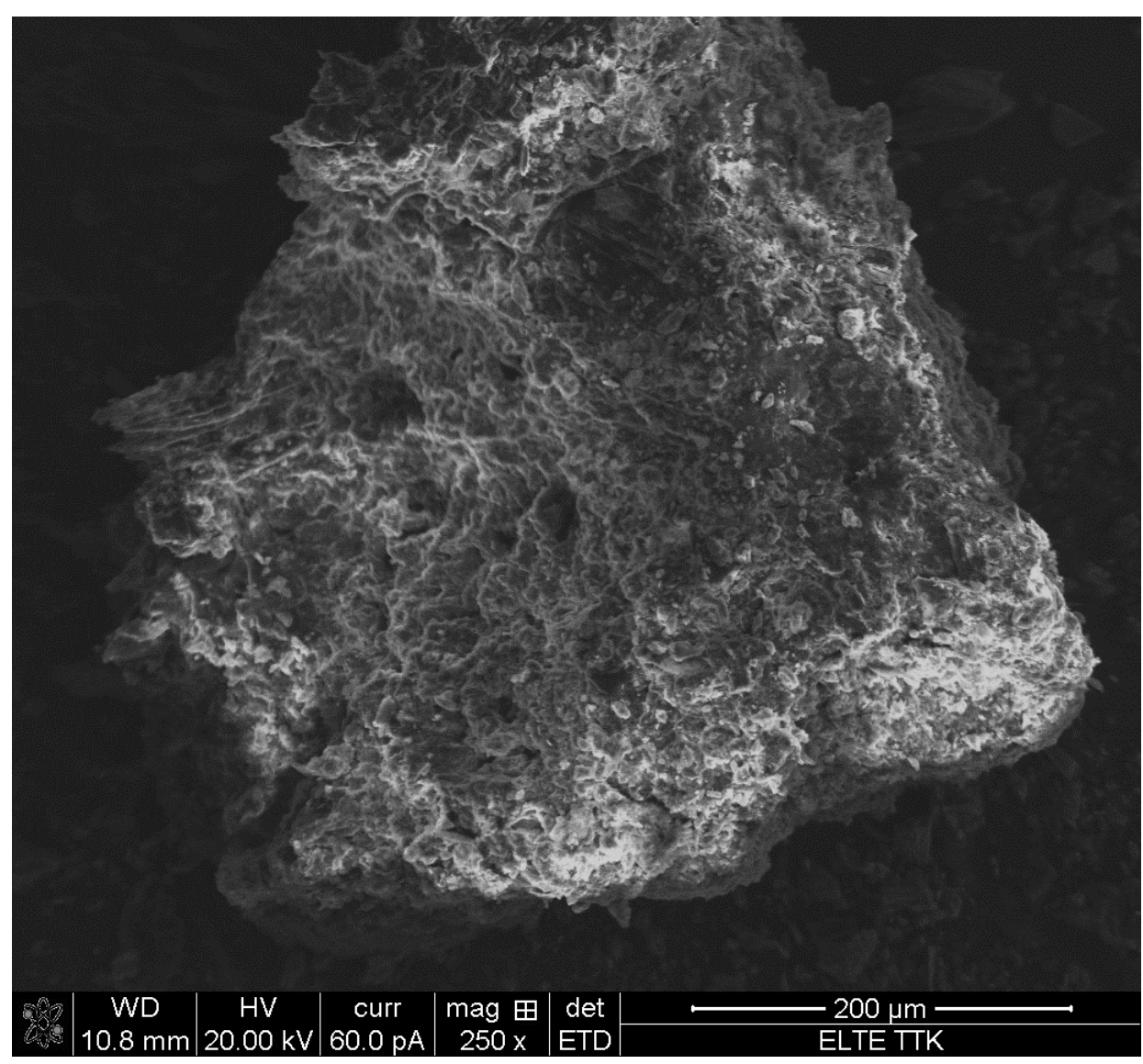


Figure 3.

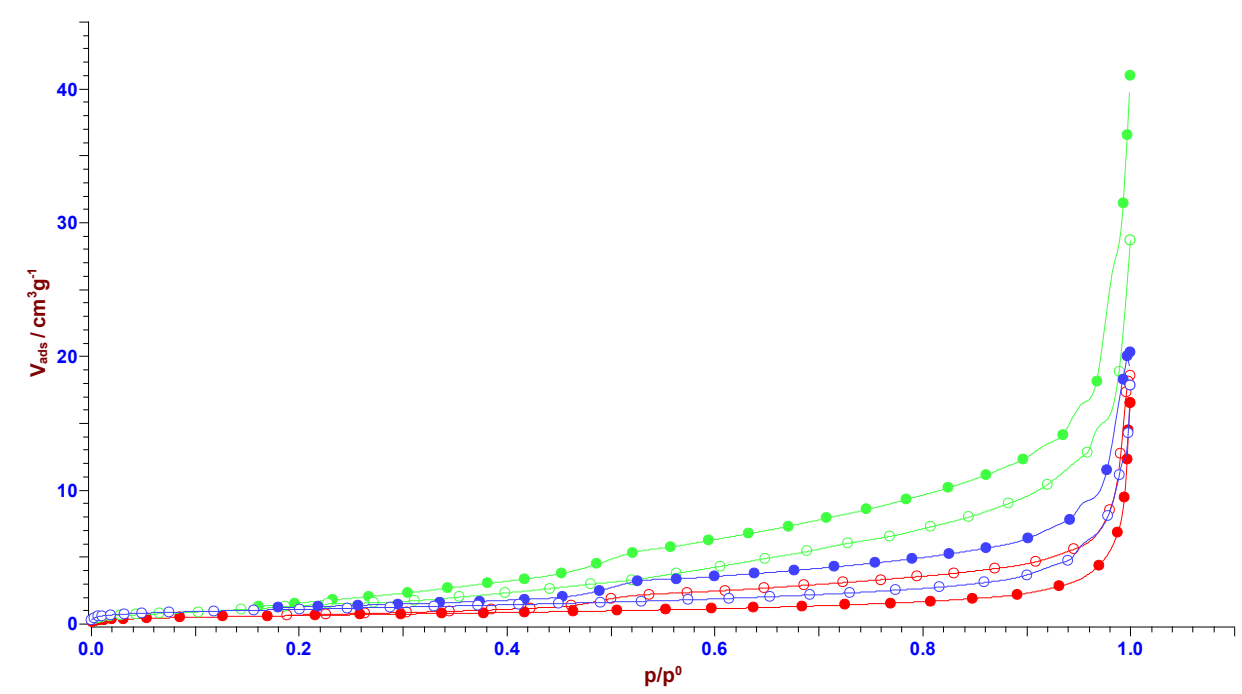


Figure 4.
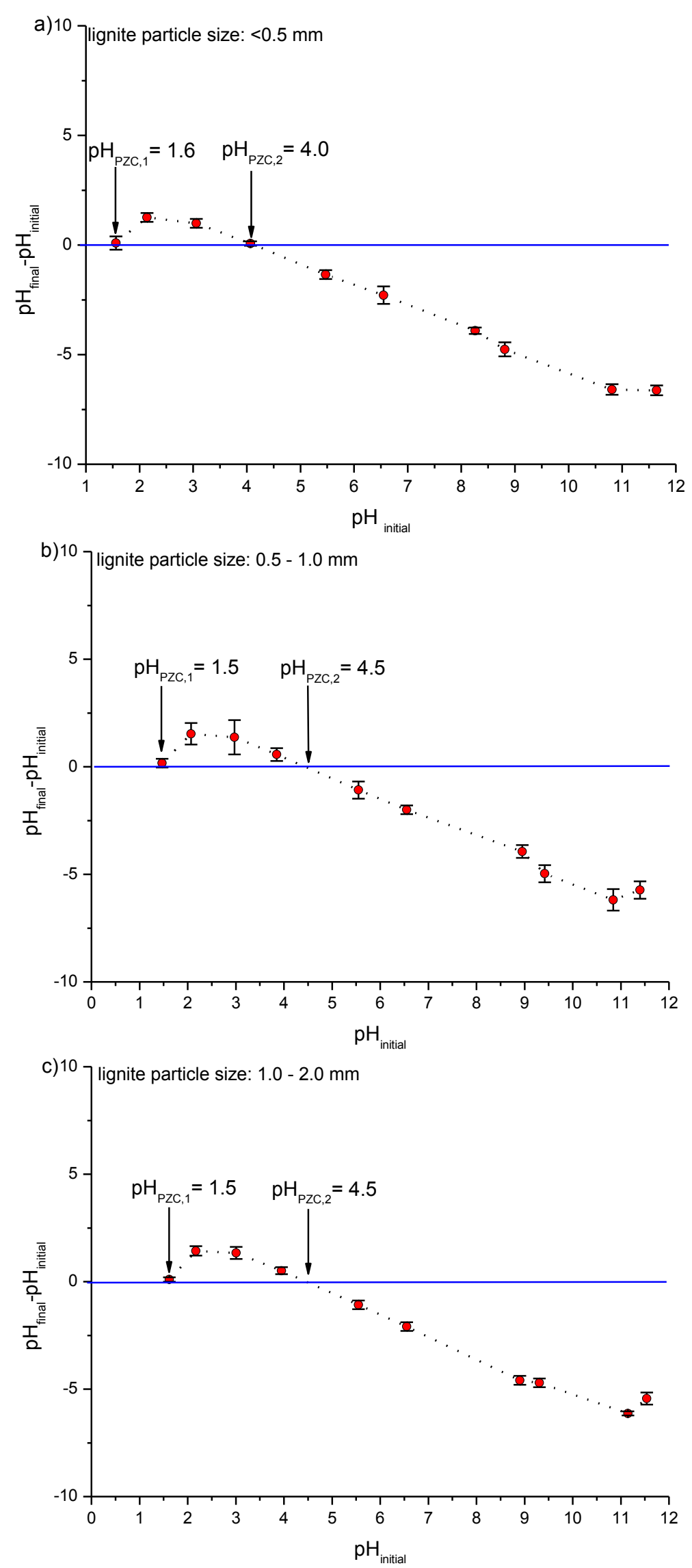
Figure 5.

a)

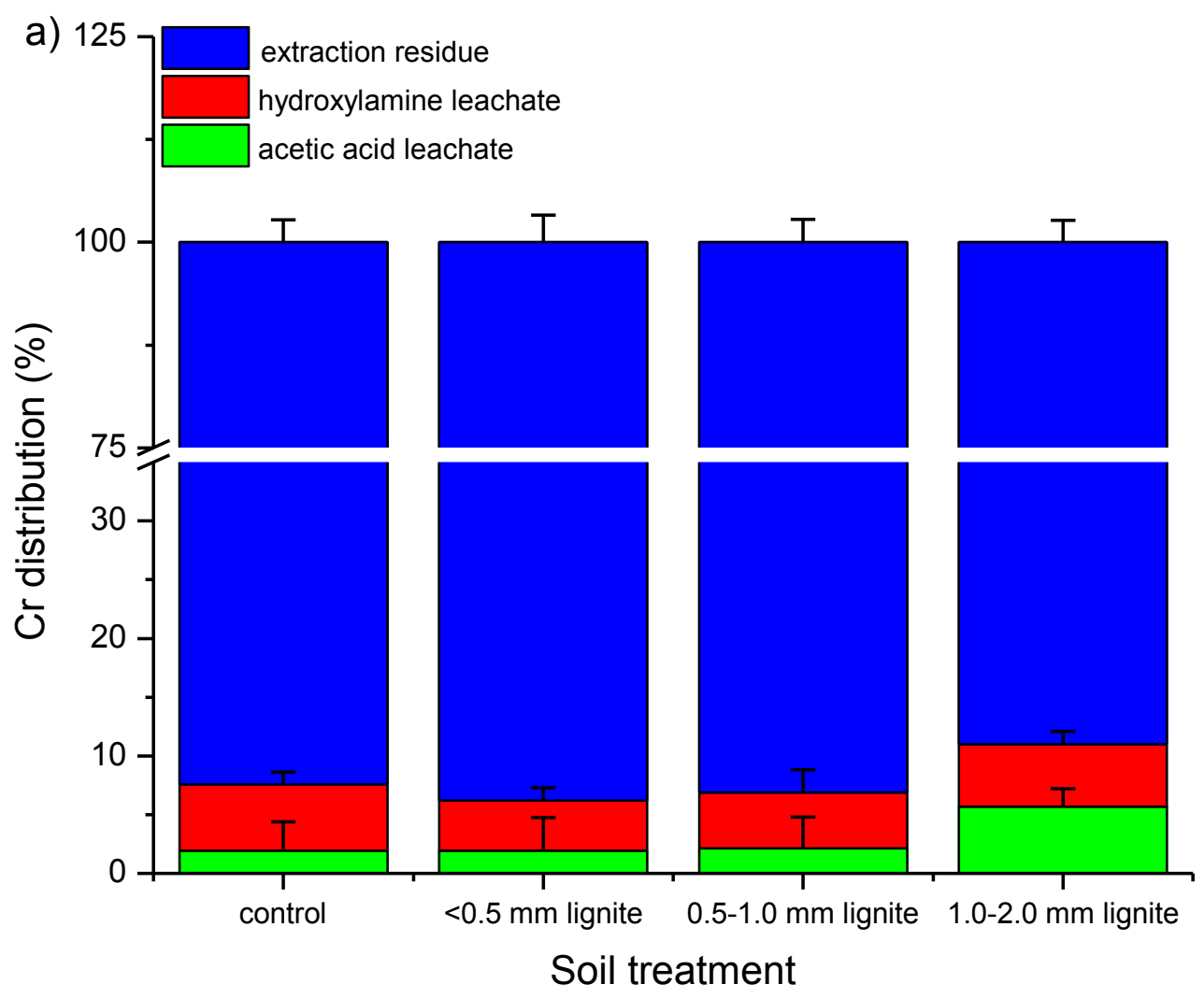

b)

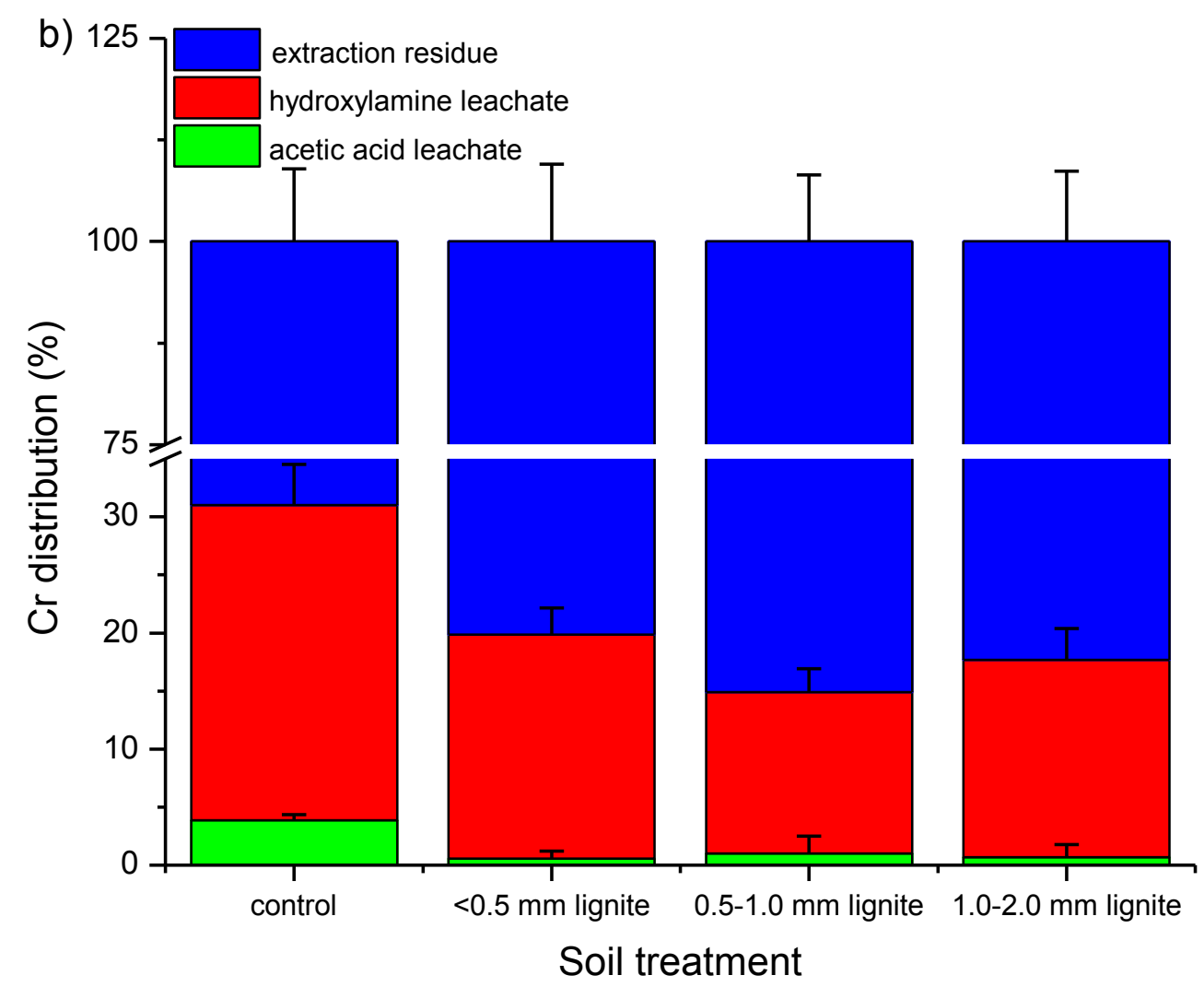


Figure 6.

a)

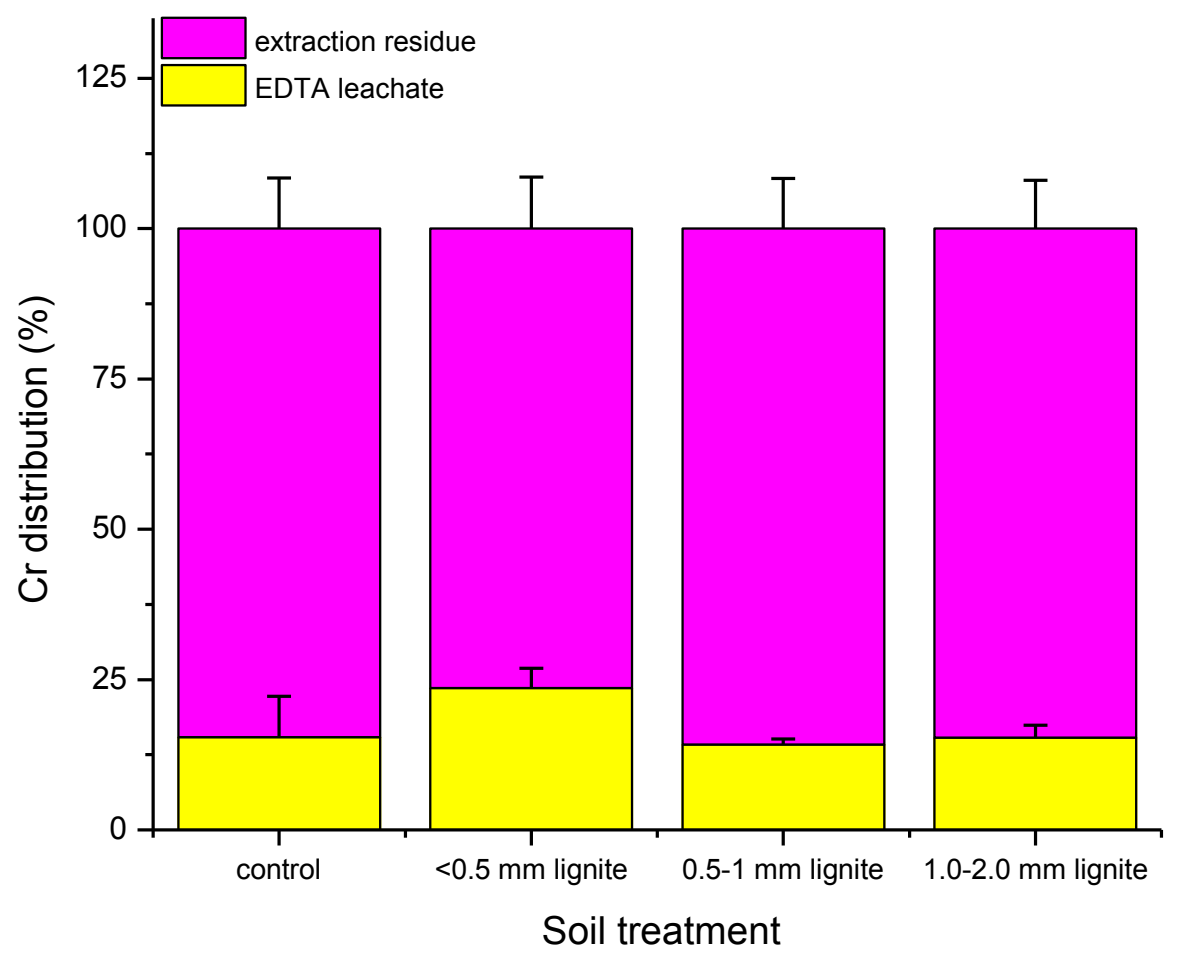

b)

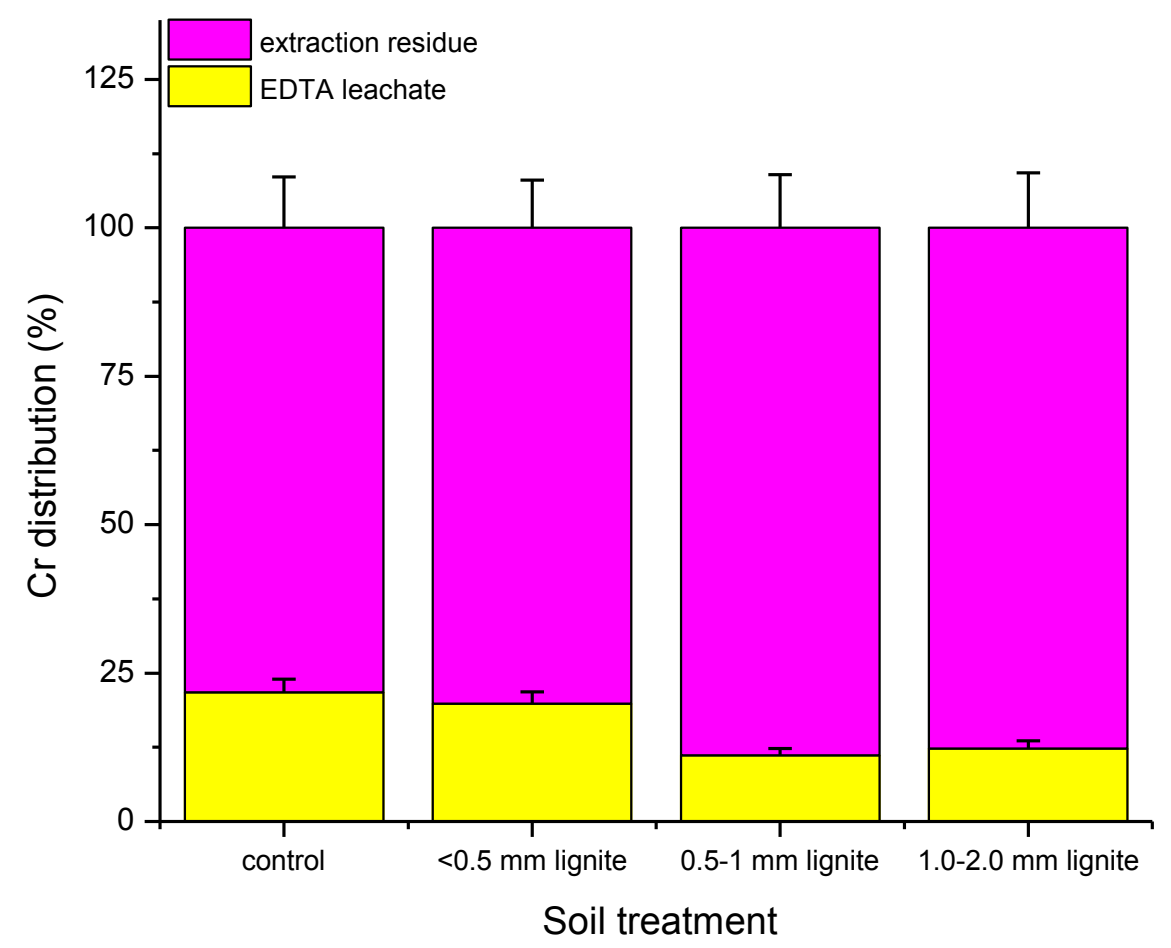




\section{Tables}

Table 1. Physicochemical characterization of the studied soil and lignite samples

\begin{tabular}{|c|c|c|c|}
\hline Parameter & Acidic sandy soil & $\begin{array}{l}\text { Calcareous sandy } \\
\text { soil }\end{array}$ & Lignite \\
\hline $\mathrm{pH}$ & 5.0 & 7.7 & 4.2 \\
\hline Upper limit of plasticity $\left(\mathrm{K}_{\mathrm{A}}\right)$ & 26 & 27 & n.a. \\
\hline Salt content $(\%)$ & $<0.02$ & n.a. & n.a. \\
\hline $\mathrm{CEC}(\mathrm{mEQ} / 100 \mathrm{~g})$ & 5 & 5 & 10 \\
\hline Sand, $>0.05 \mathrm{~mm}(\%)$ & 85 & 81 & n.a. \\
\hline Silt, 0.05-0.002 mm (\%) & 10 & 13 & n.a. \\
\hline Clay, $<0.002 \mathrm{~mm})(\%)$ & 5 & 6 & n.a. \\
\hline Organic matter $(\%)$ & 0.5 & 1.0 & 34.5 \\
\hline Specific surface area & low & n.a. & n.a. \\
\hline $\mathrm{CaCO}_{3}$ content $(\%)$ & traces & 3.3 & n.a. \\
\hline Metal-binding capacity & low & n.a. & n.a. \\
\hline aqua regia soluble $\mathrm{Cr}(\mathrm{mg} / \mathrm{kg})$ & 4 & 5 & 23.3 \\
\hline aqua regia soluble $\mathrm{Fe}(\mathrm{mg} / \mathrm{kg})$ & 6,630 & 9,350 & 13,900 \\
\hline aqua regia soluble $\mathrm{Mn}(\mathrm{mg} / \mathrm{kg})$ & 144 & 308 & 279 \\
\hline
\end{tabular}

Abbreviations: $\mathrm{CEC}=$ cation exchange capacity; n.a. = not available. 
Table 2. Optimized operating conditions of the ICP-SF-MS measurements and monitored isotopes

RF power (W) 1200

Carrier gas (Ar) flow rate (mL/min) $\quad 14$

Auxiliary gas (Ar) flow rate $(\mathrm{mL} / \mathrm{min}) \quad 1.0$

Nebulizer gas (Ar) flow rate $(\mathrm{mL} / \mathrm{min}) \quad 1.0$

Nebulizer

Meinhard (equipped with Scott spray chamber)

Ni sampler cone diameter ( $\mathrm{mm})$

1.0

Ni skimmer cone diameter (mm)

0.8

Resolution (R)

10000 (high)

Scan mode

Peak jumping

Dwell time (s)

0.1

Detector

Electron multiplier

Monitored isotopes

${ }^{52} \mathrm{Cr},{ }^{55} \mathrm{Mn},{ }^{56} \mathrm{Fe},{ }^{115} \mathrm{In}$

Internal standard

$50 \mu \mathrm{g} / \mathrm{L}$ In for $\mathrm{Cr}, \mathrm{Fe} \& \mathrm{Mn}$

Abbreviation: ICP-SF-MS - inductively coupled plasma sector field mass spectrometry.

Table 3. Characterization of lignite porosity as a function of particle size

\begin{tabular}{ccc} 
Size fraction & Pore volume (Gurvich) at $\mathrm{p} / \mathrm{p}^{0}=0.95\left(\mathrm{~cm}^{3} / \mathrm{g}\right)$ & Surface area $\left(\mathrm{cm}^{2} / \mathrm{g}\right)$ \\
\hline$<0.5 \mathrm{~mm}$ & 0.019 & 3.6364 \\
$0.5-1.0 \mathrm{~mm}$ & 0.0086 & 3.8037 \\
$1.0-2.0 \mathrm{~mm}$ & 0.0051 & 2.2167 \\
\hline
\end{tabular}


Table 4. Total $\mathrm{Cr}$ concentrations $(\mathrm{n}=3)$ in all relevant soil sample matrices determined by means of ICP-SF-MS and TXRF

\begin{tabular}{ccc}
\hline & \multicolumn{2}{c}{$+375 \mathrm{mg} / \mathrm{kg} \mathrm{Cr}(\mathrm{III})$ treatment } \\
\cline { 2 - 3 } & \multicolumn{2}{c}{ concentration $(\mathrm{mg} / \mathrm{kg} \pm \mathrm{SD})$} \\
\cline { 2 - 3 } & \multicolumn{2}{c}{ ICP-SF-MS } \\
\hline Analytical technique & acidic soil $+0.5-1.0 \mathrm{~mm} \varnothing$ lignite \\
\hline Sample matrix & $33.5 \pm 2.9$ & $41.5 \pm 4.1$ \\
AcOH leachate & $64.0 \pm 5.8$ & $65.5 \pm 4.5$ \\
$\mathrm{NH}_{2} \mathrm{OH}$ leachate & $25.7 \pm 2.1$ & $23.4 \pm 2.2$ \\
EDTA leachate & $349 \pm 9$ & $352 \pm 43$ \\
pseudo-total & alkaline soil $+0.5-1.0 \mathrm{~mm} \varnothing$ lignite \\
\hline Sample matrix & $16.0 \pm 2.5$ & $16.7 \pm 3.4$ \\
AcOH leachate & $64.0 \pm 3.8$ & $54.0 \pm 4.0$ \\
$\mathrm{NH}_{2} \mathrm{OH}$ leachate & $26.4 \pm 2.5$ & $26.7 \pm 2.5$ \\
EDTA leachate & $359 \pm 7$ & $341 \pm 22$ \\
pseudo-total & &
\end{tabular}

Abbreviations: ICP-SF-MS - inductively coupled plasma sector field mass spectrometry; SD - standard deviation; TXRF - total-reflection X-ray fluorescence spectrometry.

Table 5. Total $\mathrm{Cr}$ concentration $(\mathrm{n}=3)$ for the relevant soil treatments compared to the sum of the concentrations in various leachate fractions.

\begin{tabular}{|c|c|c|c|c|}
\hline \multirow{2}{*}{$\begin{array}{c}\text { Soil treated with } \\
375 \mathrm{mg} / \mathrm{kg} \mathrm{Cr} \text { in form of } \mathrm{Cr}(\mathrm{III})\end{array}$} & \multirow[t]{2}{*}{ Leaching test } & \multicolumn{2}{|c|}{$\begin{array}{l}\text { Cr concentration } \\
(\mathrm{mg} / \mathrm{kg} \pm \mathrm{SD})\end{array}$} & \multirow{2}{*}{$\begin{array}{l}\text { Recovery rate } \\
(\%)\end{array}$} \\
\hline & & pseudo-total & $\sum$ fractions & \\
\hline \multicolumn{5}{|c|}{ Acidic sandy soil } \\
\hline \multirow[t]{2}{*}{+ no lignite } & fit-for-purpose BCR & $347 \pm 8$ & $322 \pm 12$ & 108 \\
\hline & phytoavailability & & $354 \pm 6$ & 98 \\
\hline \multirow{2}{*}{$+<0.5 \mathrm{~mm}$ sized lignite } & fit-for-purpose BCR & \multirow{2}{*}{$349 \pm 9$} & $296 \pm 15$ & 118 \\
\hline & phytoavailability & & $350 \pm 4$ & 99 \\
\hline \multirow{2}{*}{$+0.5-1.0 \mathrm{~mm}$ sized lignite } & fit-for-purpose BCR & \multirow{2}{*}{$343 \pm 10$} & $352 \pm 5$ & 97 \\
\hline & phytoavailability & & $345 \pm 6$ & 99 \\
\hline \multirow[t]{2}{*}{$+1.0-2.0 \mathrm{~mm}$ sized lignite } & fit-for-purpose BCR & \multirow{2}{*}{$330 \pm 12$} & $364 \pm 3$ & 91 \\
\hline & phytoavailability & & $343 \pm 8$ & 96 \\
\hline \multicolumn{5}{|c|}{ Calcareous sandy soil } \\
\hline \multirow[t]{2}{*}{ + no lignite } & fit-for-purpose BCR & \multirow[t]{2}{*}{$357 \pm 7$} & $322 \pm 10$ & 111 \\
\hline & phytoavailability & & $355 \pm 4$ & 101 \\
\hline \multirow{2}{*}{$+<0.5 \mathrm{~mm}$ sized lignite } & fit-for-purpose BCR & \multirow{2}{*}{$342 \pm 6$} & $347 \pm 5$ & 99 \\
\hline & phytoavailability & & $372 \pm 2$ & 92 \\
\hline \multirow[t]{2}{*}{$+0.5-1.0 \mathrm{~mm}$ sized lignite } & fit-for-purpose BCR & \multirow{2}{*}{$359 \pm 7$} & $324 \pm 9$ & 111 \\
\hline & phytoavailability & & $352 \pm 4$ & 102 \\
\hline \multirow[t]{2}{*}{$+1.0-2.0 \mathrm{~mm}$ sized lignite } & fit-for-purpose BCR & \multirow{2}{*}{$377 \pm 8$} & $320 \pm 11$ & 118 \\
\hline & phytoavailability & & $364 \pm 3$ & 104 \\
\hline
\end{tabular}

Abbreviations: BCR - Community Bureau of Reference; SD - standard deviation. 